\title{
PEMBUATAN BOBA KOPI BIJI SALAK SEBAGAI PANGAN FUNGSIONAL SUMBER ANTIOKSIDAN
}

\author{
Kristian Triatmaja Raharja ${ }^{1)}$, Anis Nur Chabibah ${ }^{2)}$, I Wayan Sudarmayasa ${ }^{3)}$ Ita Fatkhur \\ Romadhoni ${ }^{4}$ ) \\ ${ }^{1,2)}$ Program Studi Perhotelan, Politeknik NSC Surabaya \\ 3) Program Studi Pariwisata, Politeknik Negeri Samarinda \\ 4) Program Studi Pendidikan Tata Boga, Universitas Negeri Surabaya \\ Email: kristiantraharja@gmail.com ${ }^{1)}$ \\ Asal Negara: Indonesi
}

\begin{abstract}
ABSTRAK
Biji salak yang tidak dikonsumsi secara langsung sebagai pangan ternyata memiliki potensi nilai tambah produk. Kopi biji salak terbukti memiliki kandungan kafein yang rendah, senyawa antioksidan, dan memiliki potensi ekonomi yang tinggi. Minuman boba adalah komoditas minuman dengan penjualan yang tinggi. Penelitian ini dilakukan untuk mengkaji proses pembuatan boba kopi biji salak, dan mengetahui pengaruh penambahan ekstrak kopi biji salak terhadap sifat sensori, dan aktivitas antioksidan boba. Studi eksperimental menggunakan desain rancangan acak lengkap, dengan perlakuan penambahan ekstrak kopi biji salak sebesar 20\% (X1), 40\% (X2), 60\% (X3), 80\% (X4), dan 100\% (X5). Daya terima responden terhadap produk boba dianalisis dengan uji hedonik. Aktivitas antioksidan dianalisis dengan metode penangkapan radikal DPPH, dan antioksidan asam askorbat digunakan sebagai kontrol pembanding. Hasil uji hedonik menunjukkan bahwa penambahan ekstrak kopi biji salak berpengaruh nyata terhadap parameter warna, aroma, rasa, dan keseluruhan, namun tidak berpengaruh pada tekstur. Pada uji DPPH, penambahan ekstrak kopi biji salak berpengaruh nyata terhadap aktivitas antioksidan boba. Produk terbaik berdasarkan uji hedonik untuk keseluruhan atribut sensori adalah produk boba dengan penambahan ekstrak kopi biji salak 100\% (X5), dengan skor 4,13 (skala penerimaan suka sangat suka). Produk X5 memiliki aktivitas antioksidan dengan Nilai $\mathrm{IC}_{50} 391,0 \mu \mathrm{g} / \mathrm{mL}$.
\end{abstract}

Kata kunci: antioksidan, boba, biji, kopi, salak

\section{ABSTRACT}

Snake fruit seeds that are not consumed directly as food have the potential to add value product. Snake fruit seed coffee is proven to have low caffeine content, antioxidant compounds, and high economic potential. Boba drink is a beverage commodity with increased sales. This research was conduct to study the process of making snake fruit seed coffee boba and determine the effect of snake fruit seed coffee extract on sensory properties and antioxidant activity of boba. The experimental study used a completely randomized design, with the addition of $20 \%$ (X1), 40\% (X2), 60\% (X3), 80\% (X4), and 100\% (X5) coffee extracts. The panelist's acceptance of the boba was analyzed using the hedonic test. The antioxidant activity was examined by the DPPH radical scavenging method, and the antioxidant ascorbic acid was used as a control. The hedonic test results showed that the addition of snake fruit seed coffee extract significantly affected the parameters of color, aroma, taste, and overall, but had no effect on texture. In the DPPH test, the addition of snake fruit seed coffee extract significantly impacted boba's antioxidant activity. The best product based on the hedonic test for all sensory attributes is the boba with 100\% snake fruit seed coffee extract (X5), with a score of 4.13 (like - very like acceptance scale). Product X5 has a low category of antioxidant activity with an IC50 value of $391.0 \mu \mathrm{g} / \mathrm{mL}$.

Keywords: antioxidant, boba, coffee, seed, snake fruit

\section{PENDAHULUAN}

Pengelolaan limbah yang tepat dapat membawa keuntungan secara ekonomi. Biji salak merupakan limbah dalam produksi makanan olahan buah salak. Teknologi yang telah berkembang, ditemukan bahwa kopi dapat diolah dari penyangraian biji salak (Lokaria \& Susanti, 2018). Menurut penelitian yang telah dilakukan pada kelompok usaha di Kabupaten Tapanuli didapatkan hasil nilai tambah dari produksi kopi biji salak sebesar Rp. 34.237/kg. Produksi biji salak menjadi kopi memberi keuntungan $35,99 \% / \mathrm{kg}$, perolehan margin Rp. $79.500 / \mathrm{kg}$, dengan rasio nilai tambah sebesar 42,80 (Amanda \& Baroroh, 2017).

Kopi biji salak memiliki beberapa keunggulan antara lain adalah memiliki senyawa antioksidan dan rendah kafein. Senyawa antioksidan dalam bentuk fenol, flavonoid, dan tannin mengurangi dampak buruk radikal bebas (Werdyani et al., 2017). Kandungan kafein kopi biji salak 10,9 kali lebih rendah jika dibandingkan dengan kopi liberika, 7,4 kali dengan robusta, 5,8 kali dengan arabika, 23 kali dengan kopi luwak robusta dan 25 kali lebih rendah jika dibandingkan dengan kopi instan (Chan \& 
Garcia, 2011; Karta et al., 2015; Werdyani et al., 2017). Kandungan kafein yang lebih rendah pada kopi biji salak diduga memberi manfaat kesehatan yang lebih baik, namun tetap dapat menikmati sensasi layaknya meminum kopi (Lokaria \& Susanti, 2018; Ompi et al., 2012).

Bagian buah salak terdiri dari daging buah, kulit buah dan biji (Mazumdar et al., 2019). Daging buah salak sebagian besar dikonsumsi segar, selebihnya diolah menjadi makanan olahan. Pada industri yang mengolah daging buah salak akan menghasilkan limbah, yaitu biji dan kulit. Limbah biji salak yang dihasilkan cukup besar karena biji merupakan $30 \%$ bagian secara keseluruhan dari buah salak. Melihat potensinya yang besar, sangat disayangkan bila biji salak tidak diolah secara optimal. Hal tersebut terlihat dari observasi di lapangan bahwa biji salak dengan kualifikasi tertentu dimanfaatkan sebagai benih oleh petani, selebihnya biji hanya dibuang begitu saja.

Boba atau bubble pearl adalah salah satu bahan dalam pembuatan produk minuman bubble milk tea. Boba pertama kali dikenal dan populer di Asia pada tahun 1990an, kemudian semakin populer di Eropa, serta Amerika Serikat pada awal tahun 2000. Boba terbuat dari tapioka yang dibentuk bulat dan direbus menghasilkan bulatan kenyal yang ditambahkan pada minuman panas atau dingin seperti teh, kopi, smoothie, slushie, atau minuman campuran lainnya (Chang, 2012).

Minuman boba sangat populer di kota-kota besar seperti Los Angeles, London, di Indonesia seperti Jakarta dan Surabaya. Bukti kepopuleran minuman ini di Amerika Serikat adalah pada kolom pencarian Yelp menggunakan kata kunci " $b o b a$ milk tea" menghasilkan lebih dari 500 daftar penjual boba milk tea, ini hanya di kota Los Angeles (Yelp, 2019). Minuman boba adalah komoditas minuman dengan penjualan yang tinggi.

Biji salak yang merupakan limbah dengan jumlah yang relatif banyak dan dapat diolah menjadi kopi. Kopi biji salak mempunyai beberapa keunggulan, yaitu antara lain adalah memiliki nilai ekonomi yang tinggi, bahan antioksidan, dan rendah kafein. Boba merupakan bahan tambahan bubble milk tea yang merupakan produk minuman dengan tingkat penjualan yang tinggi. Penelitian ini dilakukan untuk mengkaji proses pembuatan boba kopi biji salak, dan mengetahui pengaruh penambahan ekstrak kopi biji salak terhadap sifat sensori, dan aktivitas antioksidan boba kopi biji salak.

\section{METODE PENELITIAN}

\subsection{Bahan}

Sampel buah salak dengan usia tanam 4-5 bulan diambil dari Petani Salak di Desa Jatirejo, Kecamatan Diwek, Jombang. Buah salak yang dipilih adalah yang matang di pohon. Pemilihan salak matang dengan melihat ciri-ciri fisik, yaitu warna kulit buah merah kehitaman dan mengkilat, bulu-bulu kulit telah hilang, kulit sisik jarang, ujung bagian buah meruncing dan terasa lunak bila ditekan.

\subsection{Pembuatan Kopi Biji Salak}

Prosedur pembuatan kopi biji salak mengacu pada modifikasi metode yang dikemukakan oleh Lokaria dan Susanti (2018). Buah salak matang dikupas dan diambil biji buahnya. Biji salak dicuci hingga bersih, kemudian dipotong. Biji kemudian dikeringkan dengan dioven selama 7 jam, dengan suhu $50^{\circ} \mathrm{C}$. Biji salak kering disangrai dengan api sedang selama 60 menit, hingga berwarna gelap (gambar 1). Biji salak digiling dengan dengan grind size fine $(200-400 \mu \mathrm{m})$.

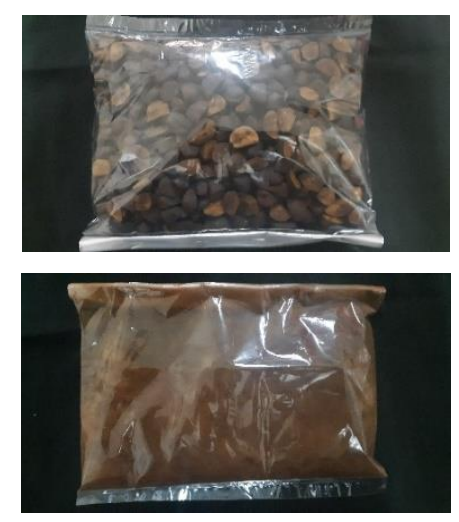

Gambar 1. Hasil kopi biji salak

\subsection{Pembuatan Ekstrak Kopi Biji Salak}

Prosedur pembuatan ekstrak kopi biji salak mengacu pada modifikasi metode yang dikemukakan oleh Asiah et al. (2017). Sebanyak 100 g bubuk kopi biji salak dilarutkan dalam $500 \mathrm{~mL}$ air panas dengan suhu $100^{\circ} \mathrm{C}$. Ekstrak dituang dan dibiarkan selama 24 jam. Selanjutnya ekstrak disaring menggunakan kain kasa atau kertas saring.

\subsection{Pembuatan Boba Kopi Biji Salak}

Prosedur pembuatan boba kopi biji salak didasarkan pada modifikasi penelitian sebelumnya, yang dilakukan Syaeftiana (2017). Bahan kering dicampur hingga rata, ditambahkan dengan ekstrak kopi biji salak dengan suhu $100^{\circ} \mathrm{C}$, diaduk hingga kalis. Adonan dibentuk bulat-bulat kecil, direbus dengan suhu $100^{\circ} \mathrm{C}$ selama 23 menit, boba yang telah matang ditandai dengan terbentuknya lapisan bening pada permukaan boba. Setelah matang boba ditiriskan dan didinginkan. Gambar 2 adalah penampilan boba yang telah matang.

Studi eksperimental dengan desain rancangan acak lengkap, perlakuan yang diberikan adalah penambahan ekstrak kopi biji salak sebesar 20, 40, 60 , 80, dan $100 \%$ dari total jumlah cairan (Tabel 1).

Tabel 1

Formulasi boba kopi biji salak 


\begin{tabular}{lccccc}
\hline Bahan & X1 & X2 & X3 & X4 & X5 \\
\hline Tapioka (g) & 270 & 270 & 270 & 270 & 270 \\
Gula (g) & 78 & 78 & 78 & 78 & 78 \\
Air (mL) & 96 & 72 & 48 & 24 & 0 \\
Ekstrak kopi biji & 24 & 48 & 72 & 96 & 120 \\
salak (mL) & & & & & \\
\hline
\end{tabular}

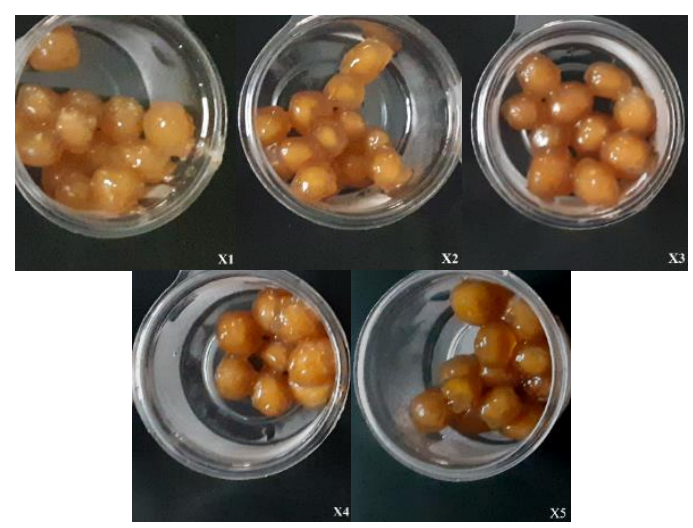

Gambar 2. Hasil boba dengan penambahan ekstrak kopi biji salak

\subsection{Uji Organoleptik}

Uji organoleptik didasarkan pada metode uji penerimaan berupa uji hedonik dengan parameter warna, aroma, rasa, tekstur/kekenyalan, dan keseluruhan. Skala uji hedonik 1-5 dengan kriteria skor adalah sangat suka (5), suka (4), cukup suka (3), tidak suka (2), sangat tidak suka (1). Uji Hedonik

\section{HASIL DAN PEMBAHASAN}

\subsection{Hasil Organoleptik Uji Hedonik Boba Kopi} Biji Salak

Hasil analisa statistik menunjukkan data berdistribusi normal pada semua perlakuan $(\mathrm{p}>0,05)$ dan varian data homogen. Uji ANOVA one way menunjukkan adanya perbedaan tingkat penerimaan dengan menggunakan panelis semi terlatih sebanyak 30 orang. Terhadap sifat bahan yang diuji, panelis bertindak sebagai instrumen analisis sensori yang mengemukakan responnya.

\subsection{Uji Aktivitas Antioksidan}

Uji aktivitas antioksidan dilakukan dengan metode Andrianto et al. (2015) dengan beberapa modifikasi untuk penyesuaian sampel. Larutan DPPH dibuat dengan 1,6 mg DPPH dilarutkan ke dalam $10 \mathrm{~mL}$ methanol, distirer selama 30 menit. Larutan kemudian ditambah dengan 10 $\mathrm{mL}, 0,1 \mathrm{M}$ bufer tris $\mathrm{HCl}$ dengan $\mathrm{pH}$ 7,4, dan $10 \mathrm{~mL}$ metanol $20 \%$. Selanjutnya didalam tabung dimasukkan masing-masing 300, 270, 240, 210, 180, dan $150 \mu \mathrm{l}$ metanol $80 \%$, dan campuran DPPH sebanyak $0,9 \mathrm{~mL}$ ditambahkan pada setiap tabung. Masing-masing tabung dimasukkan 0, 30, 60, 90, 120, dan $150 \mu$ larutan sampel $100 \mathrm{ppm}$. Konsentrasi akhir pada setiap tabung adalah 0 , 2,5, 5, 7,5, 10, dan 12,5 ppm. Setiap tabung diinkubasi 30 menit, lalu absorbansi diukur dengan spektrofotometer pada panjang gelombang $520 \mathrm{~nm}$. Antioksidan asam askorbat digunakan sebagai kontrol pembanding.

\subsection{Analisa Data}

Menggunakan SPSS versi 22, normalitas data dilakukan dengan uji shapiro wilk, homogenitas data dianalisis dengan uji levene. Untuk menganalisa perbedaan antar kelompok perlakuan, dilakukan uji ANOVA one way dan uji LSD. Taraf kepercayaan 95\% dalam pengujian statistik.

responden yang bermakna $(\mathrm{p}<0,05)$ pada atribut warna, aroma, rasa, dan tingkat kesukaan keseluruhan. Pada atribut tekstur/kekenyalan tidak menunjukkan adanya perbedaan penerimaan yang nyata $(\mathrm{p}>0,05)$. Analisis rerata tingkat penerimaan responden terhadap sampel boba kopi biji salak disajikan dalam Tabel

Tabel 2

Distribusi tingkat kesukaan boba kopi biji salak

\begin{tabular}{lccccc}
\hline \multirow{2}{*}{ Atribut } & \multicolumn{4}{c}{ Xerata skor daya terima formula } \\
\cline { 2 - 5 } & $2,66 \pm 1,212^{\mathrm{b}}$ & $3.23 \pm 1,006^{\mathrm{a}}$ & $3,46 \pm 0,776^{\mathrm{a}}$ & $3,60 \pm 1,069^{\mathrm{a}}$ & $3,53 \pm 1,166^{\mathrm{a}}$ \\
\hline Warna & $2,96 \pm 1,217^{\mathrm{d}}$ & $3,46 \pm 1,105^{\mathrm{bcd}}$ & $3,63 \pm 0,808^{\mathrm{ac}}$ & $3,80 \pm 0,886^{\mathrm{ab}}$ & $4,13 \pm 0,973^{\mathrm{a}}$ \\
Aroma & $3,16 \pm 1,019^{\mathrm{c}}$ & $3,33 \pm 0,958^{\mathrm{bc}}$ & $3,63 \pm 0,808^{\mathrm{ac}}$ & $3,66 \pm 0,884^{\mathrm{ab}}$ & $3,93 \pm 1,014^{\mathrm{a}}$ \\
Rasa & $3,36 \pm 1,299^{\mathrm{a}}$ & $3,56 \pm 1,104^{\mathrm{a}}$ & $3,53 \pm 0,973^{\mathrm{a}}$ & $3,56 \pm 1,104^{\mathrm{a}}$ & $3,36 \pm 1,299^{\mathrm{a}}$ \\
Tekstur/ & $3,13 \pm 1,074^{\mathrm{c}}$ & $3.40 \pm 0,894^{\mathrm{bc}}$ & $3.63 \pm 0,808^{\mathrm{b}}$ & $3.80 \pm 0,996^{\mathrm{ab}}$ & $4.13 \pm 0,860^{\mathrm{a}}$ \\
Kekenyalan & & & & \\
Keseluruhan & 3,134 &
\end{tabular}

Keterangan :

Menunjukkan perbedaan yang signifikan jika huruf di atas angka berbeda, pada baris yang sama. Berdasar uji LSD pada taraf kepercayaan $95 \%$

$\mathrm{X} 1=$ penambahan ekstrak kopi biji salak sebesar $20 \%$

$\mathrm{X} 2=$ penambahan ekstrak kopi biji salak sebesar $40 \%$

$\mathrm{X} 3=$ penambahan ekstrak kopi biji salak sebesar $60 \%$

$\mathrm{X} 4=$ penambahan ekstrak kopi biji salak sebesar $80 \%$

$\mathrm{X} 5 \quad=$ penambahan ekstrak kopi biji salak sebesar $100 \%$ 


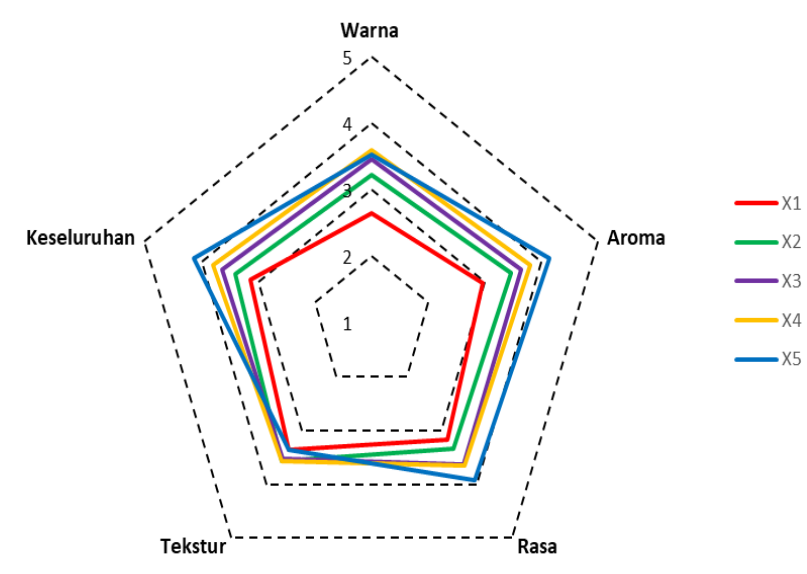

Gambar 3. Spider web diagram hasil uji hedonik boba kopi biji salak

\subsubsection{Warna}

Gambar 3 menunjukkan semakin banyak persentase ekstrak kopi biji salak semakin tinggi tingkat kesukaan produk pada atribut warna. Rerata daya terima terhadap warna boba kopi biji salak berkisar antara 2,66 (X1) sampai 3,60 (X4). Skor tertinggi pada boba dengan penambahan ekstrak kopi biji salak $80 \%$ (X4), yang berada pada skala penerimaan cukup suka sampai suka. Pada tabel 2 hasil uji LSD penerimaan atribut warna, menunjukkan tidak adanya adanya perbedaan yang bermakna antara formula X4 dengan formula X2, $\mathrm{X}$ 3, dan X5 ( $>$ >0,05), namun menunjukkan adanya perbedaan yang bermakna dengan formula X1 $(\mathrm{p}<0,05)$.

Warna merupakan parameter penting dalam menentukan pangan akan dikonsumsi atau tidak oleh konsumen. Penelitian yang dilakukan Spence (2015) menunjukkan bahwa warna makanan/minuman mempengaruhi kemampuan konsumen untuk mengidentifikasi rasa serta aroma dengan benar, dan membentuk profil rasa. Pada pembuatan boba, semakin banyak penambahan ekstrak kopi biji salak, semakin gelap warna boba yang dihasilkan. Pada penelitian ini warna boba yang dihasilkan antara cokelat muda hingga cokelat tua, semakin gelap warna boba semakin tinggi skor penerimaan responden. Tingginya skor penerimaan pada warna boba yang lebih gelap, diduga karena produk boba komersial di pasaran yang sedang diminati saat ini berwarna cokelat, cokelat tua hingga hitam. Proses sangrai biji salak menjadi kopi merubah warna biji salak, yang berpengaruh pada hasil jadi boba kopi biji salak. Terdapat tiga tahap reaksi kimia dan fisika dalam proses roasting biji, pertama yaitu evaporasi biji, selanjutnya penguapan senyawa volatil, dan terakhir adalah pirolisis (pencoklatan biji) serta reaksi Maillard. Saat tahap pirolisis terjadi dekomposisi senyawa hidrokarbon pada biji karena pemanasan, setelah suhu $180^{\circ} \mathrm{C}$ warna biji menjadi coklat kehitaman (Susila, 2016). Pada proses roasting, biji salak mengalami reaksi Maillard, yaitu reaksi kimia antara asam amino dan gula pereduksi yang membuat warna biji menjadi lebih gelap (Hu et al., 2020).

\subsubsection{Aroma}

Rerata penerimaan atribut aroma pada Gambar 3, menunjukkan adanya peningkatan tingkat kesukaan dengan semakin banyak persentase penambahan ekstrak kopi biji salak. Rerata daya terima terhadap aroma boba kopi biji salak berkisar antara 2,96 (X1) sampai 4,13 (X5). Skor tertinggi pada boba dengan penambahan ekstrak kopi biji salak 100\% (X5), yang berada pada skala penerimaan suka sampai sangat suka. Pada tabel 2 hasil uji LSD penerimaan atribut aroma, menunjukkan tidak adanya adanya perbedaan yang bermakna antara formula X5 dengan formula X3 dan $\mathrm{X} 4$ ( $\mathrm{p}>0,05)$, namun menunjukkan adanya perbedaan yang bermakna dengan formula X1 dan X2 $(p<0,05)$.

Dalam produksi makanan, aroma mempunyai peranan yang besar terutama untuk menunjukkan profil rasa, dan juga menjadi daya tarik produk (Wijk et al., 2018). Pada penelitian ini semakin banyak penambahan ekstrak kopi biji salak pada boba, semakin beraroma kopi salak yang khas, dan semakin besar daya terima responden terhadap produk boba. Proses penyangraian biji salak, merupakan proses pengembangan aroma kopi biji salak (Lokaria \& Susanti, 2018). Selama proses penyangraian terjadi perubahan perubahan fisik dan kimiawi biji kopi (reaksi Maillard dan degradasi Strecker) yang terdegradasi menjadi aroma dan rasa kopi; senyawa volatil, asam nikotinat, dan turunan piridin (Jeszka-skowron et al., 2020). Pada akhir proses penyangraian hanya $5 \%$ dari semua senyawa volatil yang dapat dideteksi oleh hidung manusia dan mempengaruhi persepsi rasa. Tingkat pemanasan yang berbeda dapat mempengaruhi profil aroma yang dihasilkan (Esposito et al., 2020).

\subsubsection{Rasa \\ Pada Gambar 3 hasil uji hedonik} menunjukkan bahwa semakin besar persentase penambahan ekstrak kopi biji salak semakin tinggi tingkat kesukaan produk pada atribut rasa. Rerata daya terima terhadap rasa boba kopi biji salak berkisar antara 3,16 (X1) sampai 3,93 (X5). Skor tertinggi pada boba dengan penambahan ekstrak kopi biji salak 100\% (X5), yang berada pada skala penerimaan cukup suka sampai suka. Pada tabel 2 hasil uji LSD penerimaan atribut aroma, menunjukkan tidak adanya adanya perbedaan yang bermakna antara formula X5 dengan formula X3 dan $\mathrm{X} 4$ ( $\mathrm{p}>0,05)$, namun menunjukkan adanya perbedaan yang bermakna dengan formula X1 dan X2 $(p<0,05)$.

Pada penelitian ini semakin banyak penambahan ekstrak kopi biji salak pada boba, semakin berasa khas kopi biji salak, dan semakin besar skor penerimaan responden. Rasa merupakan sensasi kumpulan dari aroma, tekstur, suhu makanan, 
dan juga rasa itu sendiri. Hanya setelah rasa dipadukan dengan aroma akan muncul rasa makanan tersebut (Boesveldt \& de Graaf, 2017). Penelitian yang dilakukan Lokaria dan Susanti (2018) menjelaskan bahwa rasa khas kopi biji salak dengan lama penyangraian 40 menit yaitu sepat, namun penyangraian 50-70 menit memberikan penerimaan rasa yaitu pahit. Lama proses penyangraian berbanding lurus dengan warna dan rasa kopi biji salak yaitu semakin hitam dan pahit (Prayogo et al., 2016). Sesuai dengan penelitian di atas, pada penelitian ini penyangraian dilakukan selama 60 menit yang menghasilkan kopi biji salak yang berasa pahit (Ayuni et al., 2017). Pada pembuatan boba, ekstrak kopi biji salak dicampur dengan gula dan bahan lain yang membuat rasa menjadi padu dan memiliki daya terima yang lebih baik.

\subsubsection{Tekstur/kekenyalan}

Pada Tabel 2 hasil uji LSD pada atribut tekstur/kekenyalan, menunjukkan tidak adanya perbedaan penerimaan tingkat kesukaan responden. Rerata daya terima terhadap tekstur/kekenyalan $b o b a$ kopi biji salak berkisar pada skala penerimaan cukup suka sampai suka $(3,36-3,56)$. Penambahan ekstrak kopi biji salak pada boba tidak berpengaruh terhadap penerimaan sensori tekstur boba kopi biji salak.

Tekstur makanan memberi sinyal sensori kepada konsumen. Baik dan buruknya kondisi suatu makanan sebagian besar dinilai dari sinyal sensori tekstur yang ditangkap oleh konsumen. Peran penting dari tekstur, seperti kekenyalan dalam produksi makanan adalah tekstur mengindikasikan kesegaran dan stabilitas produk (Jeltema et al., 2016). Pada penelitian ini kelima formula boba kopi biji salak menghasilkan tekstur boba yang kenyal, dan tidak memberikan perbedaan penerimaan sensori. Penambahan ekstrak cair dalam bentuk persentase dari total jumLah cairan, menyebabkan hasil jadi tekstur boba relatif sama, yaitu kenyal. Sesuai dengan itu hasil penelitian yang dilakukan Syaeftiana (2017), kekenyalan boba dihasilkan dari interaksi bahan utama (tapioka) dengan cairan saat proses pengolahan dan pemanasan. Pengurangan tepung tapioka berpengaruh besar terhadap tekstur boba yang dihasilkan.

\subsubsection{Keseluruhan}

Rerata penerimaan atribut keseluruhan pada Gambar 3, menunjukkan adanya peningkatan tingkat kesukaan dengan semakin banyak persentase penambahan ekstrak kopi. Rerata daya terima keseluruhan boba kopi biji salak berkisar antara 3,13 (X1) sampai 4,13 (X5). Pada tabel 2 hasil uji LSD penerimaan atribut keseluruhan, menunjukkan tidak adanya adanya perbedaan yang bermakna antara formula X5 dengan formula X4 ( $>>0,05)$, namun menunjukkan adanya perbedaan yang bermakna dengan formula $\mathrm{X} 1, \mathrm{X} 2$, dan $\mathrm{X} 3(\mathrm{p}<0,05)$. Mutu sensori secara keseluruhan merupakan penilaian responden terhadap produk yang bertujuan untuk mengetahui tingkat kesukaan responden pada keseluruhan atribut yang ada pada produk. Berdasarkan penilaian pada atribut keseluruhan, boba dengan penambahan ekstrak kopi biji salak $100 \%$ (X5) merupakan formula yang memiliki skor kesukaan tertinggi. Penerimaan kesukaan produk X5 berada pada skala penerimaan suka sampai sangat suka.

\subsection{Hasil Uji Aktivitas Antioksidan Boba Kopi Biji Salak}

Tabel 3

Pengujian aktivitas antioksidan boba kopi biji salak

\begin{tabular}{ll}
\hline Kode Sampel & $\begin{array}{l}\text { Rerata nilai } \mathrm{IC}_{50} \\
(\mu \mathrm{g} / \mathrm{mL})\end{array}$ \\
\hline $\mathrm{X} 1$ & $1208,6^{\mathrm{a}}$ \\
$\mathrm{X} 2$ & $1208,6^{\mathrm{a}}$ \\
$\mathrm{X} 3$ & $663,2^{\mathrm{b}}$ \\
$\mathrm{X} 4$ & $416,9^{\mathrm{c}}$ \\
X5 & $391,0^{\mathrm{c}}$ \\
Vitamin C & $14,7^{\mathrm{d}}$ \\
\hline
\end{tabular}

Keterangan :

Menunjukkan perbedaan yang signifikan jika huruf diatas angka berbeda. Berdasar uji LSD pada taraf kepercayaan $95 \%$

Aktivitas antioksidan boba kopi biji salak ditentukan menggunakan metode DPPH dengan antioksidan pembandingnya adalah asam askorbat. Pada metode ini digunakan parameter nilai $\mathrm{IC}_{50}$ yang menunjukkan konsentrasi antioksidan yang mampu meredam oksidasi radikal bebas sebesar $50 \%$. Semakin besar nilai $\mathrm{IC}_{50}$, maka semakin rendah aktivitas antioksidan untuk meredam oksidasi radikal bebas. Hasil uji pada Tabel 3 menunjukkan bahwa asam askorbat memiliki aktivitas tertinggi dengan nilai $\mathrm{IC}_{50}$ sebesar $14,7 \mu \mathrm{g} / \mathrm{mL} \quad$ dan terdapat perbedaan nyata dengan nilai $\mathrm{IC}_{50}$ kelima formula boba kopi biji salak. Formula X5 dengan penambahan ekstrak kopi biji salak $100 \%$, memiliki aktivitas tertinggi dengan nilai $\mathrm{IC}_{50}$ sebesar 391,0 $\mu \mathrm{g} / \mathrm{mL}$. Penambahan persentase ekstrak kopi biji salak, berbanding lurus dengan bertambahnya aktivitas antioksidan pada boba. Sejalan dengan hasil penelitian ini, penelitian yang dilakukan Karta et al. (2015) kopi biji salak produksi kelompok tani Desa Sibetan, Bali memiliki aktivitas antioksidan yang diukur menggunakan metode DPPH memiliki nilai IC50 sebesar 9,37 mg/mL. Aktivitas antioksidan pada kopi biji salak diduga berasal dari kandungan senyawa fenolik; flavonoid, dan tannin (Ariviani et al., 2013; Susila, 2016). Senyawa fenolik memiliki bioktivitas sebagai antioksidan, karena adanya gugus hidroksil pada cincin aromatik mempengaruhi kestabilan ikatan atom oksigen dan atom hidrogen. Ketidakstabilan ikatan tersebut membuat senyawa 
fenolik bertindak sebagai donor atom hidrogen kepada radikal bebas (Raharja et al., 2017).

\section{KESIMPULAN DAN SARAN}

Hasil penelitian menunjukkan bahwa penambahan ekstrak kopi biji salak berpengaruh nyata terhadap parameter warna, aroma, rasa, dan keseluruhan, namun tidak berpengaruh pada tekstur. Penambahan ekstrak kopi biji salak juga berpengaruh nyata terhadap aktivitas antioksidan boba kopi biji salak. Formula X5 dengan penambahan ekstrak kopi biji salak $100 \%$, memiliki aktivitas tertinggi dengan nilai $\mathrm{IC}_{50}$ sebesar $391,0 \mu \mathrm{g} / \mathrm{mL}$. Produk terbaik berdasarkan uji hedonik untuk keseluruhan atribut sensori adalah produk boba dengan penambahan ekstrak kopi biji salak 100\% (X5), dengan skor 4,13 (skala penerimaan suka - sangat suka). Produk X5 memiliki aktivitas antioksidan dengan Nilai IC $_{50} 391,0$ $\mu \mathrm{g} / \mathrm{mL}$.

\section{DAFTAR PUSTAKA}

Amanda, R., \& Baroroh, L. (2017). The Study Of The Utilization Of Limbah Salak Based On The Analysis Of Added Value And Feasibility Of Agribusiness. Agrium, 21(1), 1-7.

Andrianto, D., Katayama, D., \& Suzuki, D. (2015). Screening Of Antioxidant And Antihyperlipidemic Potencies Of Indonesian Underutilized Fruits. $J$ Forest Biomass Utilization Soc, 1, 19-25.

Ariviani, S., Her, N., \& Parnanto, R. (2013). Kapasitas Antioksidan Buah Salak (Salacca Edulis Reinw) Kultivar Pondoh, Nglumut Dan Bali Serta Korelasinya Dengan Kadar Fenolik Total Dan Vitamin C. AGRITECH, 33(3), 324333. https://doi.org/10.22146/agritech.9555

Asiah, N., Septiyana, F., Saptono, U., Cempaka, L., \& Sari, D. A. (2017). Identifikasi Cita Rasa Sajian Tubruk Kopi Robusta Cibulao. Barometer, 2(July), 52-56.

Ayuni, N. W. D., Sari, I. G. A. M. K. K., \& Adiaksa, I. M. A. (2017). Market Testing Terhadap Produk Kopi Biji Salak. PROSIDING SENTRINOV TAHUN 2017, 3, 383-396.

Boesveldt, S., \& de Graaf, K. (2017). The Differential Role Of Smell And Taste For Eating Behavior. Perception, 46((3-4), 307319. https://doi.org/10.1177/0301006616685576

Chan, S., \& Garcia, E. (2011). Comparative Physicochemical Analyses Of Regular And Civet Coffee. The Manila Journal of Science, 7(1), 19-23.

Chang, D. (2012). Is this the Inventor of Bubble Tea? CNN International. http://edition.cnn.com/travel/article/bubbletea-inventor/index.html.

Esposito, F., Fasano, E., Vivo, A. De, Velotto, S., Sarghini, F., \& Cirillo, T. (2020). Processing
Effects On Acrylamide Content In Roasted Coffee Production. Food Chemistry Journal, 319(August 2019), 1-7. https://doi.org/10.1016/j.foodchem.2020.1265 50.

Hu, G., Peng, X., Gao, Y., Huang, Y., Li, X., \& Su, H. (2020). Effect Of Roasting Degree Of Coffee Beans On Sensory Evaluation : Research From The Perspective Of Major Chemical Ingredients. Food Chemistry, 331(January), 1-10 https://doi.org/10.1016/j.foodchem.2020.1273 29

Jeltema, M., Beckley, J., \& Vahalik, J. (2016). Food Texture Assessment And Preference Based On Mouth Behavior. Food Quality and Preference, 52, 160-171. https://doi.org/10.1016/j.foodqual.2016.04.01 0

Jeszka-skowron, M., Frankowski, R., \& ZgołaGrześkowiak, A. (2020). Comparison Of Methylxantines, Trigonelline, Nicotinic Acid And Nicotinamide Contents In Brews Of Green And Processed Arabica And Robusta Coffee Beans - Influence Of Steaming, Decaffeination And Roasting Processes On Coffee Beans. Food Science and Technology, 125(109344), 1-9. https://doi.org/10.1016/j.lwt.2020.109344

Karta, I. W., Susila, A. N. K., Mastra, I. N., \& Dikta, P. G. A. (2015). Kandungan Gizi Pada Kopi Biji Salak (Salacca Zalacca) Produksi Kelompok Tani Abian Salak Desa Sibetan Yang Berpotensi Sebagai Produk Pangan Lokal Berantioksidan Dan Berdaya Saing. Jurnal Virgin, 1(2), 123-133.

Lokaria, E., \& Susanti, I. (2018). Uji Organoleptik Kopi Biji Salak Dengan Varian Waktu Penyangraian. BIOEDUSAINS: Jurnal Pendidikan Biologi Dan Sains, 1(2), 34-42.

Mazumdar, P., Pratama, H., Lau, S., How, C., \& Ann, J. (2019). Trends In Food Science \& Technology Biology, Phytochemical Profile And Prospects For Snake Fruit: An Antioxidant- Rich Fruit Of South East Asia. Trends in food science \& technology, 91, 147158. https://doi.org/10.1016/j.tifs.2019.06.017

Ompi, G. F., Pakasi, C. B. D., \& Benu, N. M. (2012). Strategi Pemasaran Kopi Biji Salak "KOBISA" Di Desa Pangu Kecamatan Ra- Tahan Timur Kabupaten Minahasa Tenggara. COCOS: Jurnal Ilmiah Fakultas Pertanian Universitas Sam Ratulangi, 7(1), 1-6.

Prayogo, K., Wulandari, W., \& Suhartatik, N. (2016). Pembuatan Kopi Biji Salak (Salacca Zalacca) Dengan Variasi Lama Penyangraian Dan Penambahan Bubuk Jahe. Jurnal Teknologi Dan Industri Pangan, 1(2), 69-78.

Raharja, K. T., Wirjatmadi, B., \& Adriani, M. (2017). Pemberian Buah Kawista Menghambat Peningkatan Kadar Malondialdehid Serum 
Tikus Wistar Yang Dipapar Asap Rokok. Jurnal Kedokteran Brawijaya, 29(3), 190-195.

Spence, C. (2015). On The Psychological Impact Of Food Colour. Flavour, 4(1), 1-16. https://doi.org/10.1186/s13411-015-0031-3

Susila, L. A. N. K. E. (2016). Salacca Coffee Made Of Snake Fruit Seed Waste. International Conference of Young Scientists. https://doi.org/10.3390/antiox2040230

Syaeftiana, N. A. (2017). Formulasi Bubble Pearls Dengan Penambahan Tepung Torbangun (Coleus amboinicus Lour). (Skripsi) Fakultas Teknologi Pertanian, Institut Pertanian Bogor.

Werdyani, S., Jumaryatno, P., \& Khasanah, N. (2017). Antioxidant Activity Of Ethanolic Extract And Fraction Of Salak Fruit Seeds ( Salacca zalacca (gaertn.) voss. ) using DPPH (2,2-diphenyl-1- picrylhydrazyl) method. Eksakta: Jurnal Ilmu-Ilmu MIPA, 17(2), $137-$ 146.

Wijk, R. A. De, Smeets, P. A. M., Polet, I. A., Holthuysen, N. T. E., Zoon, J., \& Vingerhoeds, M. H. (2018). Aroma Effects On Food Choice Task Behavior And Brain Responses To Bakery Food Product Cues. Food Quality and Preference, 68(February), 304-314. https://doi.org/10.1016/j.foodqual.2018.03.01 5.

Yelp. (2019). Best Boba Milk Tea In Los Angeles. https://www.yelp.com/search?find_desc=boba milk tea\&find_loc=Los Angeles\%2C CA\&start $=750$. 